\title{
ANALISIS FAKTOR-FAKTOR YANG MEMPENGARUHI WAJIB PAJAK DALAM PENGURUSAN RESTITUSI PAJAK PADA KANTOR PELAYANAN PAJAK PRATAMA BENGKULU
}

\author{
Hapizar Triansyah \\ Karona Cahya Susena \\ Program Studi Akuntansi \\ Fakultas Ekonomi Universitas Dehasen Bengkulu
}

\begin{abstract}
ABSTRAK
Hapizar Triansyah, Karona Cahya Susena; Tujuan dari penelitian ini yaitu untuk mengetahui Faktor-Faktor Apa Saja Yang Dominan Mempengaruhi Wajib Pajak Dalam Pengurusan Restitusi Pajak Pada Kantor Pelayanan Pajak Pratama Bengkulu. . analysis results can be used as consideration Bengkulu Pratama Tax Office to improve the management of restitution in the future. Type of research is descriptive qualitative. researchers also conducted a descriptive analysis of the dominant factors that affect taxpayers in obtaining refunds of taxes. in this study also uses data analysis to reating scale raw data is numeric then interpreted in a qualitative sense, so measurements using this scale reating change in processing quantitative data into kaulitatif. Hasil penelitian menghasilkan bahwa dari lima indikator jumlah responden menyatakan pernyataan tentang pengurusan restitusi pajak dengan skor 165,1 berada pada interval 146 - 179 yang berada pada daerah berpengaruh. Hal ini menyatakan bahwa kelima indikator tersebut dalam pengurusan restitusi pajak berpengaruh bagi wajib pajak. pengurusan restitusi pajak yang berpartisipasi mengisi kuesioner secara umum menyatakan tanggapan yang sangat baik. Sesuai grafik kontinum kita ketahui bahwa pernyataan yang dominan adalah Prosedur Restitusi dengan skor 188,6 berada pada interval 180 - 213 yang berada pada daerah sangat berpengaruh menduduki urutan tertinggi.
\end{abstract}

\begin{abstract}
Hapizar Triansyah, Karona Cahya Susena; The purpose of this research is to determine the Factors Affecting What Are The Dominant taxpayer Handling Tax Refund Kantor Pelayanan Pajak Pratama bengkulu. analysis results can be used as consideration Bengkulu Pratama Tax Office to improve the management of restitution in the future. Type of research is descriptive qualitative. researchers also conducted a descriptive analysis of the dominant factors that affect taxpayers in obtaining refunds of taxes. in this study also uses data analysis to reating scale raw data is numeric then interpreted in a qualitative sense, so measurements using this scale reating change in processing quantitative data into kaulitatif. Produce research results that of the five indicators of the number of respondents expressed a statement about obtaining tax refunds with a score of 165.1 is in the interval 146-179 that are in the area of effect. It is stated that the five indicators in the management of tax refunds for taxpayers affected. Processing of tax refunds that participate filled out a questionnaire in general expressed a very good response. Continuum corresponding graphs we know that the statement is the dominant procedure with a score of 188.6 Restitution is in the interval 180-213 which was very influential in the area of the highest ranks.
\end{abstract}

Key words: Sanctions, Period of Restitution, Restitution Procedures, Tax Audit, Tax Officer

\section{PENDAHULUAN}

Lembaga pemerintah menghimpun penerimaan dalam negeri dari sektor pajak, yang berguna untuk membiayai anggaran penyelengaraan pemerintah pelayanan umum, dan pembangunan nasional. Pembangunan nasional yang bersama-sama kita laksanakan dalam rangka mewujudkan masyarakat yang adil dan makmur memerlukan dana yang besar. Peran serta masyarakat dalam membiayai pembangunan dan penyelenggaraan roda pemerintahan 
sangat diperlukan antara lain, dengan melakukan kewajiban dalam membayar pajak yang merupakan sebagai sumber penerimaan negara yang dominan.

Pembangunan merupakan indikator suatu bangsa dalam mewujudkan kesejahteraan masyarakatnya. Untuk dapat melanjutkan pembangunan, pemerintah harus dapat mengupayakan semua potensi penerimaan yang ada. Pembangunan dapat dilaksanakan dengan lancar apabila sumber dana yang mendukung. Sumber pendapatan terbanyak didapat dari sektor perpajakan meskipun masih banyak sektor lain seperti minyak dan gas bumi, serta bantuan luar negeri dan tidak dapat dipungkiri lagi bahwa pajak telah memberikan kontribusi besar dalam penerimaan Negara.

Akhir-akhir ini Pemerintah gencar melakukan berbagai upaya untuk meningkatkan penerimaan dari sektor pajak. Penentuan target penerimaan yang sangat tinggi dan selalu meningkat secara signifikan dari tahun ke tahun merupakan salah satu bukti, pajak merupakan primadona bagi sumber pendapatan negara.

Pada tahun 2008 proporsi terhadap penerimaan pajak negara terus meningkat dari 67 persen menjadi 73,2 persen pada tahun 2012 dari total APBN.

(http://www.pikiran-rakyat.com/node/23684-jam19.42/29Desember2013).

Adapun tujuan dari penelitian ini yaitu untuk mengetahui Faktor-Faktor Apa Saja Yang Dominan Mempengaruhi Wajib Pajak Dalam Pengurusan Restitusi Pajak Pada Kantor Pelayanan Pajak Pratama Bengkulu.

Dari besaran tersebut dapat dibayangkan suatu tugas dan tanggung jawab yang cukup dan berat namun didukung oleh kesadaran dan kepedulian masyarakat khususnya para Wajib Pajak dalam memenuhi kewajiban perpajakan, sehingga rencana penerimaan pajak tersebut akan tercapai. Self assessment system yang diterapkan di Indonesia memberikan wewenang kepada Wajib Pajak untuk menghitung, membayar, dan melaporkan besarnya pajak terutang yang harus dibayar oleh Wajib Pajak. Pemberlakuan self assessment system di Indonesia merupakan cara pemerintah untuk memberikan kepercayaan dan tanggung jawab kepada Wajib Pajak. Akan tetapi, pemerintah tidak begitu saja melepaskan Wajib Pajak tanpa memiliki pengetahuan perpajakan. Sehingga, pemerintah memberikan pembinaan, pelayanan, dan pengawasan kepada Wajib Pajak dalam menjalankan tanggung jawab perpajakannya.

Pengajuan restitusi Pajak Pertambahan Nilai pada Undang-Undang Nomor 18 Tahun 2000 dapat dilakukan pada setiap masa pajak. Akan tetapi pada Undang-Undang Nomor 42 Tahun 2009 yang dapat melakukan restitusi pada setiap masa pajak hanya Pengusaha Kena Pajak yang melakukan ekspor Barang Kena Pajak Berwujud, penyerahan Barang Kena Pajak atau Jasa Kena Pajak kepada Pemungut PPN, penyerahan Barang Kena Pajak atau Jasa Kena Pajak yang tidak dipungut PPN, ekspor Barang Kena Pajak Tidak Berwujud, ekspor Jasa Kena Pajak, atau masih dalam tahap belum berproduksi. Selain Pengusaha Kena Pajak tersebut hanya dapat melakukan restitusi pada akhir tahun buku.

Membayar pajak merupakan kewajiban guna mendapatkan hak setiap Warga Negara ikut berpartisipasi dalam bentuk peran serta terhadap pembiayaan kewajiban pembayaran pajak sebagai pencerminan kewajiban kewarganegaraan di bidang perpajakan berada pada anggota masyarakat sendiri untuk memenuhi kewajiban tersebut. Sesuai dengan sistem self assesment yaitu wajib pajak menghitung, melaporkan dan membayar sendiri pajak terhutang yang menjadi kewajibannya. Sistem ini juga sangat bermanfaat bagi wajib pajak untuk dapat patuh dalam membayar pajak. Bagi warga negara yang telah terdaftar menjadi Wajib Pajak dan memiliki Nomor Pokok Wajib Pajak (NPWP) adalah suatu langkah awal dari kewajiban perpajakan yang baik dan benar. Undang-undang yang dipakai untuk mengatur besarnya tarif pajak, tata cara pembayaran dan pelaporan pajak adalah Undang-undang No.17 Tahun 2000 yang merupakan penyempurnaan bagi Undang-Undang terdahulunya yaitu Undang-Undang No. 10 tahun 1994.

\section{Landasan Teori}

\section{Variabel-Variabel yang terkandung dalam restitusi pajak}

1. Pajak 
Menurut Andriani (2008:8) "Pajak merupakan iuran kepada negara (yang dapat dipaksakan) yang terutang oleh yang wajib membayarnya menurut peraturan-peraturan, dengan tidak mendapat prestasi kembali, yang langsung dapat ditunjuk, dan yang gunanya adalah untuk membiayai pengeluaran umum berhubungan dengan tugas Negara yang menyelenggarakan pemerintah."

2. Wajib Pajak

Menurut Mardiasmo (2011:12) “wajib Pajak adalah orang pribadi atau badan yang menurut ketentuan peraturan perundngan-undangan perpajakan ditentukan untuk melakukan kewajiban perpajakan, termasuk pemungut pajak atau pemotong pajak tertentu".

3. NPWP

Menurut Purwono (2010:25) "NPWP adalah nomor yang diberikan kepada wajib pajak sebagai sarana dalam administrasi perpajakan yang digunakan sebagai tanda pengenal diri atau identitas Wajib Pajak dalam melaksanakan hak dan kewaiban perpajakannya".

\section{Dasar Hukum Pemungutan Pajak}

Dasar hukum pemungutan pajak diatur berdasarkan Undang-Undang dasar 1945 Pasal 23 ayat 2 yang berbunyi "segala pajak untuk keperluan negara berdasarkan Undang-Undang" Dasar hukum pajak berdasarkan Undang-Undang RI terdiri dari :

1. UU No. 6 tahun 1983 tentang Ketentuan Umum dan Tata Cara Perpajakan sebagaimana telah beberapa kali diubah terakhir dengan UU No. 28 Tahun 2007

2. UU No. 7 Tahun 1983 tentang Pajak Penghasilan (PPh) sebagaimana telah beberapa kali diubah terakhir dengan UU. No. 28 Tahun 2008

3. UU No. 12 Tahun 1985 tentang Pajak Bumi dan Bangunan (PBB) sebagaimana telah beberapa kali diubah terakhir dengan UU No. 12 Tahun 1994.

4. UU No. 13 Tahun 1985 tentang Bea Materai sebagaimana telah beberapa kali diubah terakhir dengan UU No. 24 Tahun 2000.

5. UU No. 18 Tahun 1983 tentang Pajak Pertambahan Nilai dan Penjulan dan Jasa Penjualan Atas Barang Mewah (PPN dan PPnBM) sebagaimana telah beberapa kali diubah terakhir dengan UU No. 42 Tahun 2009.

6. UU No. 18 tahun 1997 tantang Pajak Daerah dan Restribusi Daerah (PDRD) sebagaimana telah beberapa kali diubah terakhir dengan UU No. 28 Tahun 2009.

7. UU No. 19 Tahun 1997 tentang Penagihan Pajak dengan Surat Paksa (PPSP) sebagaimana telah beberapa kali diubah terakhir dengan UU No. 19 Tahun 2000.

8. UU No. 21 Tahun 1997 tentang Bea Perolehan atas Tanah dan Bangunan (BPHTB) sebagaimana telah beberapa kali diubah terakhir dengan UU No. 20 Tahun 2000.

9. UU No. 20 Tahun 1997 tentang Penerimaan Negara Bukan Pajak (PNBP) sebagaimana telah beberapa kali diubah terakhir dengan UU No. 20 tahun 1999.

10. UU No. 14 Tahun 2002 tentang Pengadilan Pajak.

\section{Fungsi Pajak}

Menurut Resmi (2012:3) Fungsi Pajak yaitu :

1. Fungsi Sumber keuangan Negara (budgetair)

Artinya pajak merupakan salah satu sumber penerimaan pemerintah untuk membiayai pengeluaran baik rutin maupun pembangunan. Sebagai sumber keuangan negara, pemerintah berupaya memasukan uang sebanyak-banyaknya untuk kas negara.

2. Fungsi Pengatur (regularend)

Artinya pajak sebagai alat untuk mengatur atau melaksanakan kebijakan pemerintah dalam bidang sosial dan ekonomi, serta mencapai tujuan-tujuan tertentu di luar bidang keuangan.

\section{Peranan Pajak}

Menurut Direktorat Jenderal Pajak (2007:4), Peranan Pajak yaitu : 
1. Mengisi anggaran pendapatan dari belanja Negara yang tercantum dalam Rancangan Anggaran, Pendapatan dan Belanja Negara (RAPBN).

2. Sebagai salah satu penghasilan pemerintah selain migas.

3. Memudahkan sarana dan prasarana bagi masyarakat dalam menjalankan hubungan antar masyarakat dengan pemerintah.

Menurut Jinghan (2008:9), Peranan Pajak sebagai berikut :

1. Untuk membatasi konsumsi dan dengan demikian mentransfer sumber dari konsumsi ke investasi.

2. Untuk meningkatkan dorongan menabung dan menanam modal.

3. Untuk mentransfer sumber dari tangan masyarakat ke tangan pemerintah sehingga memungkinkan adanya investasi pemerintah.

4. Untuk mengurangi ketimpangan ekonomi.

\section{Sistem Pemungutan Pajak}

Menurut Siti Resmi (2012:11) dalam memungut pajak dikenal beberapa sistem pemungutan yaitu :

1. Official Assessment System

Sistem pemungutan pajak yang memberi kewenangan aparatur perpajakan menentukan sendiri jumlah pajak yang tertuang setiap tahunnya sesuai dengan peraturan perundangundangan perpajakan yang berlaku.

2. Self Assessmen System

Sistem pemungutan pajak yang memberi wewenang Wajib Pajak dalam menentukan sendiri jumlah pajak yang tertuang setiap tahunnya sesuai dengan peraturan perundang-undangan perpajakan yang berlaku. Menghitung sendiri pajak yang terutang

a. Memperhitungkan sendiri pajak yang terutang

b. Membayar sendiri jumlah pajak yang terutang

c. Melaporkan sendiri jumlah pajak yang terutang

d. Mempertanggungjawabkan pajak yang terutang

Dengan demikian berhasil atau tidaknya pelaksaan pemungutan pajak banyak tergantung pada Wajib Pajak sendiri (peranan dominan ada pada Wajib Pajak).

3. With Holding System

Sistem pemungutan pajak yang memberi wewenang kepada pihak ketika yang ditunjuk untuk menentukan besarnya pajak yang terutang pada Wajib Pajak sesuai dengan peraturan perundang-undangan perpajakan yang berlaku.

\section{Jenis Pajak}

Menurut Resmi (2012:7) terdapat berbagai jenis pajak yang dapat dikelompokan menjadi 3 (tiga) yaitu :

1. Menurut golongan

a. Pajak langsung yaitu pajak yang harus dipikul atau ditanggung sendiri oleh Wajib Pajak dan tidak dapt dilimpahkan atau dibebankan kepada orang lain atau pihak lain. Pajak harus menjadi beban Wajib Pajak yang bersangkutan,

b. Pajak Tidak Langsung yaitub pajak yang pada akhirnya dapat dibebankan atau dilimpahkan kepada orang lain atau pihak ketiga. Pajak tidak langsung terjadi jika terdapat suatu kegiatan, peristiwa, atau perbuatan yang menyebabkan terutangnya pajak. Untuk menentukan apakah sesuatu termasuk pajak langsung atau pajak tidak langsung dalam arti ekonomis yaitu dengan cara meihat etiga unsur yang terdapat dalam kewaiban pemenuhan perpajakan. Ketiga unsur tersebut terdiri dari :

1) Penanggung Jawab Pajak

2) Penanggung Pajak

3) Pemikul Pajak

2. Menurut Sifat 
a. Pajak subjektif yaitu pajak yang penangannya memperhatikan keadaan pribadi Wajib Pajak atau penggenaan pajak yang memperhatikan keadaan subjeknya.

b. Pajak Objektif yaitu pajak yang penanganannya memperhatikan objeknya baik berupa benda, keadaan, perbuatan, atau peristiwa yang mengakibatkan timbulnya kewajiban membayar pajak tanpa memperhatikan keaaan pribadi Subjek Pajak maupun tempat tinggal.

\section{Restitusi Pajak}

Menurut penjelasan Pasal 11 UU KUP No. 28 Tahun 2007 "Restitusi adalah perhitungan jumlah pajak yang sebenarnya terutang dengan jumlah kredit pajak yang menunjukan selisih lebih (jumlah kredit pajak lebih besar daripada pajak yang terutang".

Restitusi Pajak adalah pengembalian Pembayaran pajak terjadi apabila jumlah kredit pajak atau jumlah pajak yang dibayar lebih besar daripada jumlah pajak ang terutang atau telah dilakukan pembayaran pajak yang tidak seharusnya terutang, dengan catatan Wajib Pajak tidak punya hutang pajak lain.

Faktor-faktor yang mempengaruhi Wajib Pajak dalam pengurusan Restitusi Pajak yaitu:

\section{Sanksi Dalam Restitusi}

Menurut Ted Honderich "Pidana adalah suatu tindakan penyalahgunaan dari pihak yang berwenang sebagai hukuman yang dikenakan kepada seseorang pelaku karena sebuah pelanggaran".

(http://www.pengertianahli.com/2013/10/pengertian-pidana-menurut-para-ahli.html-jam 19.14-10 Desember 2013).

Menurut Fidel (2010:156) yang diatur dalam Pasal 39 Undang-Undang Nomor 16 Tahun 2000 tentang Ketentuan Umum dan Tata cara Perpajakan apabila Wajib Pajak melakukan percobaan untuk melakukan tindakan pidana penyalahgunaan atau tidak lengkap dalam rangka mengajukan restitusi, ancamanya berupa pidana penjara paling lama 2 (dua) tahun dan denda paling tinggi 4 (empat) kali jumlah restitusi yang dimohon.

\section{Jangka Waktu Restitusi}

Menurut Untung Sukardji (2006:311) "Bedasarkan Pasal 17B UU KUP ditetapkan bahwa setelah melakukan pemeriksaan atas permohonan pengembalian kelebihan pembayaran pajak selain diajukan oleh Wajib Pajak dengan kriteria tertentu, harus menerbitkan surat ketetapan paling lambat 12 bulan sejak surat permohonan diterima (dalam keadaan lengkap), kesuali utuk kegiatan tertentu ditetapkan lain dengan Keputusan Direktur Jenderal Pajak.

Menurut Sukardji (2006:312) "Jangka waktu penyelesaian permohonan pengembalian kelebihan pembayaran pajak diajukan oleh PKP Kriteria tertentu tidak diatur dengan tegas dala Keputusan Direktur Jenderal Pajak No. KEP-160/PJ/2001 tersebut, sehingga seharusnya berlaku jangka waktu yang diatur dalam Pasal 17C ayat (1) UU KUP yaitu Surat Pengambilan Pendahuluan Kelebihan Pajak (SKPPKP) diterbitkan paling lambat :

a. 3 (tiga) bulan untuk Pajak Penghasilan.

b. 1 (satu) bulan untuk Pajak Pertambahan Nilai

\section{Prosedur Restitusi}

Prosedur pada dasarnya adalah suatu susunan yang teratur dari kegiatan yang berhubungan satu sama lainnya dan prosedur-prosedur yang berkaitan melaksanakan dan memudahkan kegiatan utama dari suatu organisasi".

(http://necel.wordpress.com/2009/06/28/pengertian-prosedur/jam20.14/10 Desember 2013) Sedangkan menurut Peraturan Direktorat Jenderal Pajak PER-7/PJ/2011 "Bahwa Prosedur menguraikan tata cara dalam penyelesaian pengembalian kelebihan pembayaran pajak $\mathrm{PPh}$, PPN,PPnBm kepada Wajib Pajak". 


\section{Pemeriksaan Pajak}

Menurut Muljono (2008:83)"pemeriksaan pajak adalah kegiatan menghimpun dan mengolah data, keterangan atau bukti yang dilaksanakan secara objektif dan propfesional berdasarkan suatu standar pemeriksaan untuk menguji kepatuhan pemenuhan kewajiban perpajakan atau untuk tujuan lain dalam rangka melaksanakan ketentuan perundang-undangan perpajakan.

\section{Petugas Pelayanan Pajak}

Menurut Direktorat Jenderal Pajak "Petugas Pelayanan Pajak merupakan tugas dari pelayanan yang betujuan Penatausahaan surat dan dokumen masuk serta laporan wajib pajak pada tempat pelayanan terpadu".

\section{Kerangka Analisis}

\begin{tabular}{|c|l|l|l|}
\hline $\begin{array}{c}\text { Faktor- Faktor Yang } \\
\text { Mempengaruhi Wajib } \\
\begin{array}{c}\text { Pajak Dalam } \\
\text { Pengurusan Restitusi } \\
\text { Pajak }\end{array}\end{array}$ & $\begin{array}{l}\text { 1. Sanksi } \\
\text { 2. Jangka Waktu Restitusi } \\
\text { 3. Prosedur Restitusi } \\
\text { 4. Pemeriksaan Pajak } \\
\text { 5. Petugas Pelayanan Pajak }\end{array}$ \\
\cline { 2 - 3 }
\end{tabular}

Gambar 1. Kerangka Analisis

\section{HASIL DAN PEMBAHASAN Hasil Penelitian}

Pada penelitian ini, peneliti mencoba menggambarkan faktor-faktor apa saja yang memperngaruhi Wajib Pajak dalam pengurusan Restitusi Pajak, peneliti juga melakukan analisa deskriptif terhadap faktor yang dominan yang diperoleh untuk Analisis Faktor-Faktor Yang Mempengaruhi Wajib Pajak Dalam Pengurusan Restitusi Pajak Pada Kantor Pelayanan Pajak Pratama Bengkulu.

Karena tidak semua data dan imformasi akan diproses dan tidak semua orang atau benda akan diteliti cukup yang mewakilinya. Sampel yang digunakan dalam penelitian ini adalah seluruh wajib pajak yang terdaftar di Kantor Pelayanan Pajak Pratama Bengkulu yang berjumlah sebanyak 43 Wajib Pajak. Jadi metode yang digunakan adalah metode sensus yaitu (jumlah populasi $=$ jumlah sampel).

\section{Tabel 1 Jumlah Responden Menurut Jenis Perusahaan}

\begin{tabular}{|c|c|c|c|}
\multirow{2}{*}{ No } & \multirow{2}{*}{ Jenis Perusahaan } & \multicolumn{2}{c|}{ Jumlah } \\
& Manufaktur & 23 & $53,59 \%$ \\
\hline 1 & Dagang & 15 & $34,89 \%$ \\
\hline 2 & Jasa & 5 & $11,62 \%$ \\
\hline 3 & Jumlah & $\mathbf{4 3}$ & $\mathbf{1 0 0} \%$ \\
\hline
\end{tabular}

Sumber : Hasil Penelitian Data Diolah, 2014

Berdasarkan tabel dan gambar diatas menunjukan data jumlah responden terbanyak adalah dari kelompok responden Perusahaan Manufaktur yaitu 23 Wajib Pajak atau 53,49 \% dari jumlah responden, diikuti oleh responden Perusahaan Dagang yaitu 15 Wajib Pajak atau $34,89 \%$ dan terakhir responden dengan Perusahaan Jasa yaitu 5 Wajib Pajak atau 11,62 \% 
responden. Data diatas menunjukan responden sudah mengutamakan peningkatan dalam pengurusan restitusi pajak.

a. Responden Berdasarkan Jenis Kelamin

Tabel 2 Jumlah Responden Menurut Jenis Kelamin

\begin{tabular}{|c|c|c|c|}
\hline No & Jenis Kelamin & Jumlah & Persentase \\
\hline 1 & Laki-laki & 36 & $83,72 \%$ \\
\hline 2 & Perempuan & 7 & $16,28 \%$ \\
\hline \multicolumn{2}{|c|}{ Jumlah } & 43 & $100 \%$ \\
\hline
\end{tabular}

Sumber : Hasil Penelitian Data Diolah, 2014

Berdasarkan tabel dan gambar diatas dapat diketahui bahwa responden terbanyak adalah laki-laki yaitu 36 Wajib Pajak (83,72 \%) sedangkan perempuan hanya 7 Wajib Pajak $(16,28 \%)$. Alasanya karena banyak pekerjaan dilapangan jadi butuh Wajib Pajak laki-laki ditempatkan di Kantor Pelayanan Pajak Pratama Bengkulu, sedangkan perempuan dibanding laki-laki lebih sedikit pekerjaan banyak menurusu administrasi di perusahaan.

b. Responden Berdasarkan Tingkat Pendidikan

Tabel 3 Jumlah Responden Menurut Tingkat Pendidikan

\begin{tabular}{|c|c|c|c|}
\hline No & Tingkat Pendidikan & Jumlah & Persentase \\
\hline 1 & SMA & 19 & $44,19 \%$ \\
\hline 2 & S1 & 21 & $48,83 \%$ \\
\hline 3 & S2 & 3 & $6,98 \%$ \\
\hline & umlah & 43 & $100 \%$ \\
\hline
\end{tabular}

Sumber : Hasil Penelitian Data Diolah, 2014

Tabel dan gambar diatas menunjukan data jumlah responden terbanyak dalah dari kelompok responden pendidikan pasca sarjana Strata satu (S1) yaitu 21 Wajib Pajak atau $48,83 \%$ dari jumlah responden, diikuti oleh responden dengan pendidikan SMA yaitu sebanyak 19 Wajib Pajak atau 44,19 \% responden dan terakhir responden dengan pendidikan sarjana Starata dua (S2) yaitu sebanyak 3 Wajib Pajak atau 6,98 \%. Data diatas menunjukan responden sudah mengutamakan peningkatan kualitas Wajib Pajak.

c. Responden Berdasarkan Usia

Tabel 4 Jumlah Responden Menurut Usia

\begin{tabular}{|c|c|c|c|}
\hline No & Tingkat Pendidikan & Jumlah & Persentase \\
\hline 1 & 21-30 tahun & 12 & $27,91 \%$ \\
\hline 2 & $31-40$ tahun & 24 & $55,82 \%$ \\
\hline 3 & 41-50 tahun & 5 & $11,62 \%$ \\
\hline 4 & 51-60 tahun & 2 & $4,65 \%$ \\
\hline
\end{tabular}

Sumber :Hasil Penelitian Data Diolah, 2014

Berdasarkan tabel dan gambar diatas dapat diketahui bahwa untukusia responden terbanyak adalah yang berusia 31-40 tahun sebanyak 24 Wajib Pajak $(55,82 \%)$, diikuti dengan usia responden 21-30 tahun sebanyak 12 Wajib Pajak (27,91\%), kemudia usia 
responden 41-50 tahun sebanyak 5 Wajib Pajak (11,62 \%) dan usia reponden 51-60 tahun sebanyak 2 Wajib Pajak (4,65 \%). Hal ini menunjukan bahwa kelompok usia 31-40 tahun yaitu usia yang produktif bagi Wajib Pajak yang bertugas dalam pengurusan restitusi pada Kantor Pelayanan Pajak Pratama Bengkulu.

\section{Pembahasan}

Berdasarkan hasil penelitian tentang presepsi Wajib Pajak tentang bagaimana Analisis Faktor-faktor Yang Mempengaruhi Wajib Pajak Dalam Pengurusan Restitusi Pajak Pada Kantor Pelayanan Pajak Pratama Bengkulu maka diperoleh data pada tabel dibawah ini :

Tabel 10. Persepsi Responden Mengenai Grafik Kontinum

\begin{tabular}{|c|l|c|l|}
\hline \multirow{2}{*}{ No } & Pernyataan Indikator & Jumlah Rata-rata & \multicolumn{1}{c|}{ Kriteria } \\
\hline 1 & Sanksi & 158,6 & Berpengaruh \\
\hline 2 & Jangka Waktu Restitusi & 161,4 & Berpengaruh \\
\hline 3 & Prosedur Restitusi & 188,6 & Sangat Berpengaruh \\
\hline 4 & Pemeriksaan Pajak & 158,4 & Berpengaruh \\
\hline 5 & Petugas Pelayanan Pajak & 158,8 & Berpengaruh \\
\hline
\end{tabular}

Sumber : Hasil Penelitian Data Diolah, 2014

Dari lima indikator persepsi responden mengenai pernyataan tentang pengurusan restitusi pajak rata-rata persepsi responden sebesar 165,1 yang pada interval 146 - 179 yang berada pada daerah berpengaruh. Hal ini menyatakan bahwa kelima indikator tersebut dalam pengurusan restitusi pajak berpengaruh bagi wajib pajak.

Dari persepsi responden mengenai pengurusan restitusi pajak indikator tentang Prosedur Restitusi sebesar 188,6 yang berada pada daerah sangat berpengaruh menduduki urutan tertinggi. Hal ini berarti bahwa responden paling besar memberikan dukungan terhadap pernyataan tentang prosedur restitusi, dengan kata lain responden menilai Wajib Pajak yang terdaftar pada Kantor Pelayanan Pajak Pratama Bengkulu memperhatikan pengajuan permohonan restitusi dengan persyaratan formal berupa: Surat Pengukuhan, Jenis Usaha, NPWP, Kelengkapan Pengisian SPT, dapat dilihat dari tabel bahwa Kantor Pelayanan Pajak Pratama satu tahun sekali menyusun rencana tahun berikutnya agar sesuai dengan tujuan atau sasaran.

Maka hasil dari penelitian yang penulis lakukan pada Kantor Pelayanan Pajak Pratama Bengkulu terhadap Wajib Pajak dalam pengurusan restitusi pajak berjalan sangat baik, salah satu faktornya adalah Wajib Pajak memahami prosedur restitusi yang diberikan oleh Kantor Pelayanan Pajak Pratama Bengkulu. Dengan koordinasi yang sangat baik tersebut akan berdampak positif terhadap kinerja Wajib Pajak. Tumpang tindih tugas dan tanggung jawab akan terhindar serta program yang direncanakan oleh setiap Wajib Pajak selalu berjalan sesuai dengan jadwal yang telah ditentukan.

Dengan demikian secara umum dapat dikatakan bahwa Wajib Pajak dalam pengurusan restitusi pajak pada Kantor Pelayanan Pajak Pratama Bengkulu sangat baik dan hal ini adalah tidak terlepas dari peran koordinasi yang dilakukan baik antara pegawai kantor pajak dengan wajib pajak yang terdaftar di Kantor Pelayanan Pajak Pratama Bengkulu. Artinya dalam pengurusan restitusi pajak yang dilakukan oleh Wajib Pajak mempunyai pengaruh yang signifikan pada Kantor Pelayanan Pajak Pratama Bengkulu dan diterima berdasarkan hasil penelitian.

Secara kontinum pernyataan pengurusan restitusi pajak dapat digambarkan seperti gambar. 9 dibawah ini: 


\section{Gambar 9. Grafik Kontinum Restitusi Pajak}

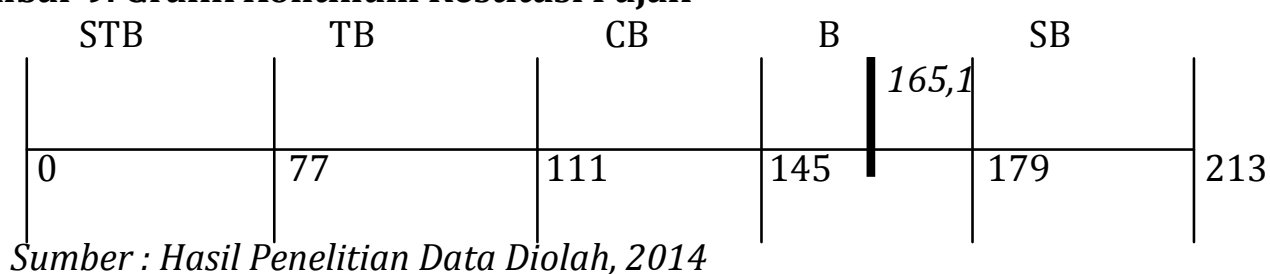

Dari gambar grafik kontinum responden mengenai restitusi pajak rata-rata persepsi responden sebesar 165,1 yang pada interval 146 - 179 yang pada daerah berpengaruh. Hal ini menyatakan bahwa kelima indikator tersebut dalam pengurusan restitusi pajak sangat penting dan berpengaruh bagi wajib pajak pada Kantor Pelayanan Pajak Pratama Bengkulu.

\section{Kesimpulan}

Berdasarkan hasil analisis dan pembahasan yang telah dilakukan oleh peneliti pada bab sebelumnya, kesimpulan yang dapat ditarik berdasarkan tujuan penelitian yakni untuk mengetahui faktor apa saja yang dominan dalam pengurusan restitusi pajak Pada Kantor Pelayanan Pajak Pratama Bengkulu adalah :

1. Dari lima indikator jumlah responden terhadap pengurusan restitusi pajak diketahui bahwa rata-rata jumlah responden sanksi pada nilai 158,6 (146 -179) dalam kriteria berpengaruh, untuk rata-rata jumlah responden jangka waktu restitusi yaitu 161,4 (146-179) pada kriteria berpengaruh, sedangkan pada rata-rata jumlah responden prosedur restitusi dengan jumlah nilai 188,6 (146-179) dalam kriteria sangat berpengaruh, selanjutnya rata-rata jumlah responden pemeriksaan pajak terdapat nilai 158,4 (146-179) pada kriteria berpengaruh dan rata-rata jumlah responden petugas pelayanan pajak dengan nilai 158,8 (146-179) dalam kriteria berpengaruh.

Berdasarkan kelima indikator tersebut pernyataan tentang pengurusan restitusi pajak dengan skor 165,1 berada pada interval 146 - 179 yang berada pada daerah berpengaruh. Hal ini menyatakan bahwa kelima indikator tersebut dalam pengurusan restitusi pajak berpengaruh bagi wajib pajak.

2. Pernyataan tentang pengurusan restitusi pajak yang berpartisipasi mengisi kuesioner secara umum menyatakan tanggapan yang sangat baik. Sesuai grafik kontinum kita ketahui bahwa pernyataan yang dominan adalah Prosedur Restitusi dengan skor 188,6 berada pada interval 180 - 213 yang berada pada daerah sangat berpengaruh menduduki urutan tertinggi. Hal ini berarti bahwa responden paling besar memberikan dukungan terhadap pengurusan restitusi pajak, dengan kata lain responden menilai Wajib Pajak yang terdaftar pada Kantor Pelayanan Pajak Pratama Bengkulu memperhatikan pengajuan permohonan restitusi dengan persyaratan formal berupa: Surat Pengukuhan, Jenis Usaha, NPWP, Kelengkapan Pengisian SPT,dapat dilihat dari tabel bahwa Kantor Pelayanan Pajak Pratama satu tahun sekali menyusun rencana tahun berikutnya agar sesuai dengan tujuan atau sasaran.

\section{Saran}

Berdasarkan kesimpulan dari hasil penelitian diatas, maka kepada Kantor Pelayanan Pajak Pratama Bengkulu disarankan sebagai berikut :

1. Agar dalam pengurusan restitusi pajak dapat dicapai dengan baik, maka prosedur restitusi menjadi faktor yang sangat penting dan menjadi yang tertinggi dalam pengurusan restitusi pajak maka sebaiknya prosedur restitusi dipertahankan agar dalam pengurusan restitusi pajak tetap tercapai dan pemeriksaan pajak menjadi yang terendah dalam pengurusan restitusi pajak maka sebaiknya lebih ditingkatkan, diberi pelatihan terhadap sumber daya manusia agar memperluas pengetahuan tentang restitusi pajak.

2. Agar Kepala Kantor selaku pimpinan, harus sering mensosialisasikan atau mengimformasikan kepada Wajib Pajak tentang pengurusan restitusi pajak. 
3. Agar koordiansi yang dilakukan dapat mendukung pencapaian tujuan yang baik, hendaknya koordinasi dilakukan dalam berbagai aspek secara menyeluruh, baik dalam koordinasi pada saat perencanaan kebiajakan/kegiatan, koordinasi dalam pelaksanaan tugas iu sendiri maupun koordinasi dalam hal pengawasan.

4. Agar pengurusan restitusi pajak dapat dicapai dengan secara baik, selain dengan menerapkan disiplin dan tanggung jawab dalam pelaksanaan restitusi pajak karena hal tersebut merupakan dorongan yang kuat dalam menumbuhkan kesadaran untuk membayar pajak dan mengabdi kepada Negara dan masyarakat.

\section{DAFTAR PUSTAKA}

Andriani. 2008. Ketentuan Umum dan Tata cara Perpajakan. Salemba Empat. Jakarta

Direktorat Jenderal pajak 2007, Nomor Pokok Wajib Pajak.

2007, Peranan Pajak,

2007, Pengertian Pajak.

Djajadiningrat. 2012. Perpajakan. Gramedia Pustaka Utama. Jakarta

Fidel. 2010. Cara Mudah Praktis Memahami Masalah-Masalah Perpajakan. Murai Kencana. Jakarta.

http://bunda-bisa.blogspot.com/2013/02/definisi-ciri-fungsi-danperananpajak.menurutpara-ahli.html-jam 20.12-29 Desember 2013

http://necel.wordpress.com/2009/06/28/pengertian-prosedur/Jam19.50/22 Juni 2013.

http://www.pikiran-rakyat.com/node/236849/Jam 19.25/28 November 2013

http://www.pengertianahli.com/2013/10/pengertian-pidana-menurut-para-ahli. html jam 20. $\underline{12}$-29 Desember 2013.

Jinghan. 2008. Pajak Perekonomian Indonesia. PT Raja Grafindo Persada. Jakarta

Mardiasmo. 2011. Perpajakan. Andi. Yogyakarta.

Mulyono Djoko. 2008. Tax Palnning Menyiasati Pajak Dengan Bijak. Andi. Yogyakarta

Pasal 11 UU KUP Nomor 28 Tahun 2007, Restitusi Pajak.

Purwono,Herry. 2010. Dasar-Dasar Perpajakan dan Akuntansi Pajak. Erlangga. Jakarta.

Resmi Siti. 2012. Perpajakan : Teori kasus. Salemba Empat. Jakarta.

Sugiyono. 2010, Metode Penelitian Bisnis. Alfabeta. Bandung.

2013, Metode Penelitian Kuantitatif Kualitatif dan R\&D. Alfabeta. Bandung.

Sukardji Untung, 2006, Pajak Pertambahan Nilai Edisi Revisi 2006. PT Raja Gafindo Persada. Jakarta.

Undang-Undang Dasar 1945 pasal 23 ayat 2, Dasar Hukum Pemungutan Pajak. 
Undang-Undang Nomor 18 tahun 2000 tentang Pengajuan Restitusi Pajak Pertambahan Nilai. Undang-Undang Nomor 17 tahun 2000 tentang Tarif pajak, Tata cara Pembayaran dan Pelaporan Pajak.

Undang-Undang Nomor 42 tahun 2009 tentang Restitusi pajak. 